\title{
REINVENTION OF THE PUBLIC SECTOR: TOTAL QUALITY MANAGEMENT AND CHANGE MANAGEMENT
}

\author{
Konstantinos M. Karyotakis ${ }^{1,}{ }^{*}$, Vassilis S. Moustakis ${ }^{1}$ \\ ${ }^{1}$ School of Production Engineering and Management, \\ Technical University of Crete, Chania, Greece
}

\begin{abstract}
:
The present article provides a review of Total Quality Management (TQM) and Change Management in Public Sector. It highlights the special role of TQM in the Public Sector, the concept of Quality in Public Sector Services, the Innovation in Public Sector and the role that E-Government can play. Moreover, it emphasizes some Best Practices that have been applied in Greece and consists of innovative and interesting practices. It concludes by integrating all concepts discussed with the factors that shape change.
\end{abstract}

\section{Key words:}

change management,

e-Government, public administration reform, public management, public organizations, TQM.

\section{INTRODUCTION}

Pursuant to the guidelines of the Lisbon European Council (March 2000), governments around the world are launching national programs for the reinvention of the state in order to change the overall government performance. This creates a result oriented and cost-conscious public administration, which will provide high quality services and satisfy the needs of its citizens.

This implies a deviation from the traditional bureaucratic management of public services towards a more entrepreneurial, so-called, New Public Management-NPM (Denhardt and Denhard, 2000). As part of this strategy, some quality tools and techniques are used, including Management By Objectives, Total
Quality Management, Balanced Scorecard, Cost-Benefit Analysis, Market Testing, Performance Related Pay, Value For Money and more, or combination of these, which have already been implemented in the private sector.

Successful implementation of quality tools, in the vast majority of cases, has a positive impact on the economic performance of organizations. However, studies undertaken in various countries around the world indicate that most quality initiatives ultimately failed to achieve the desired goals. Moreover, favorable results were produced in the short term whereas long-term sustainability was not achieved. Some researchers even declared TQM a failure and went little further to cut quality funds (Kuperus and Rode, 2008). 
As empirical evidence could not provide reasonable explanation why some quality programs offered large positive effects whilst others provided no improvement whatsoever, or any substantial improvement in business performance, some researchers began to investigate the creation of commitment to the ideals of TQM and quality, approaching the culture as a phenomenon, rather than as a set of tools and techniques.

In a quality-oriented organization, with dynamic environment, change is inevitable. The biggest obstacle to the introduction of TQM in an organization is to change the culture, that is, the period during which attempts are made to change behavior and relationships between employees in an organization and transform their organizational culture into quality culture. In order to ensure sustainable quality culture, quality should not be treated as a destination but as a journey where leadership and learning play an important role.

\section{GUIDELINES FOR DEFINING THE NOTION OF QUALITY IN THE PUBLIC SECTOR}

The concept of quality is expressed in a series of complementary definitions, as follows:

Improving the way of governance (the constitutional architecture and the structure of government and society) and the effectiveness of public action (Bovaird and Löffler, 2002; Bovaird et al., 2002; Daemen and Schaap, 2000; Matheson and HaeSang, 2003).

Quality can be defined as "the way somebody feels adequate with something" (OECD, 2001). According to another point of view, quality is a set of standards and characteristics of the product in relation to their ability to meet the needs that are known or arising (International Organization for Standardization, 2009). Conversely, quality is perceived as the level at which a set of inherent characteristics fulfills requirements, which may be subjected to different levels (International Organization for Standardization, 2000).

It is well-known that the quality of services has become an important aspect of performance in any organization in the public sector (OECD, 2001). Indeed, the public administration of nations attempts to achieve performance through strategic quality management (Matei and Lazar, 2011).

\section{QUALITY AND PUBLIC SECTOR}

There was a growing need in the early 1990s to modernize and reform the dysfunctional and bureaucratic public sector, in order to meet the current needs of the society and prosper in a highly globalized and competitive environment. Efficiency improvement in the public sector is a goal that is positioned high on the political agenda in almost all industrialized countries (Staes and Thijs, 2005).

Along with the adoption of the Lisbon agenda in 2000, Member States of the European Union (EU) have raised the difficult task of making the Union the most competitive economic area in the world, which would rely on knowledge in order to ensure sustainable growth and better work opportunities, higher social sensitivity and a simplified regulatory environment. Essentially, the Lisbon Treaty ratified the need to modernize public administration (IvanUngureanu and Marcu, 2006).

Moreover, at that time, a wave of administrative reform program was launched in several European countries (such as the English "Modeling Government", the Irish "Quality Customer Service Initiative", the German "Moderner Staat" etc.). The perception of the private sector and efforts to enhance civil society greatly influenced the content of these programs.

The main fields of administrative reforms, which are reflected in these programs, refer to:

- upgrading the quality of services provided to citizens;

- improving the efficiency and effectiveness of public services through goal setting and evaluation of organic units and employees under performance ratios;

- improving the quality of regulation (Laws, Presidential Decrees, Joint Ministerial Decisions), simplification of administrative procedures and removal of administrative barriers for citizens and entrepreneurs, as well as enhancing transparency and development of social dialogue;

- ensuring the rights of workers by strengthening the bilateral dialogue and collective bargaining;

- introducing "Electronic Government" (e-Government) by enabling citizens to have online access to public services and networking of public services between them; 
- qualitative improvement of human resources;

- strengthening of institutional transparency and control.

Basically, the public service framework focuses on three important dimensions of quality:

- The core of the service.

- The external environment of the service.

- The relationships that can be developed in the provision of services.

The achievement of the Lisbon objectives in the economic and social field implies the effective and efficient operation of the national administrations and implementation of effective and innovative practices. These reforms have brought about new principles, such as focusing on efficiency and effectiveness, ensuring transparency and accountability, providing information on public sector deliverables.

According to the Luijn et al. (2004), countries can improve the functioning of the public sector through adoption of best practices implemented in other countries.

\section{BEST PRACTICES}

Best Practice is a relative term denoting sometimes innovative and interesting business practices, which have been identified through benchmarking. Due to the rising need for continuous and substantial improvement of administrative action responsible for public administration, Ministers of the Member States of the EU agreed in November 1998, to establish "Quality Conference" as of the year 2000, which will present the "Best Practices" by all Member States, namely superior returns, methods or approaches that lead to excellent results. Such conferences have enabled creation of the network for the exchange of know-how and experiences.

Noteworthy is the fact that the number of various practices presented at the different quality conferences (which are conducted every two years) have increased over the years, giving trigger to other organizations to be inspired by the organizations that already have these best practices or to imitate them. For example:

- In 2000 in Lisbon, Portugal, 39 good practices were presented.

- In 2002 in Copenhagen, Denmark, 49 good practices were presented.
- In 2004 in Rotterdam, Netherlands, 65 good practices were presented.

- In 2006 in Tampere, Finland, 78 good practices were presented (Kazakou, 2010).

The European Institute of Public Administration (EIPA) has created a network of users of the Common Assessment Framework (CAF), which enables the exchange of knowledge and experiences through CAF implementation. Within this network, all best practices from the implementation of CAF from European organizations are gathered in a database, thus facilitating comparative modeling and securing suitable conditions for comparative learning. Everyone can search for best practices on the website of EIPA, selecting among others the criterion of a best practice that focuses on:

- Results focused on citizen / customer.

- Results for the performance of an organization.

- Leadership.

- Partnerships and resources.

- Human resources.

- Results of human resources.

- Procedures.

- Society's effect.

- In strategies and plans.

- In CAF general.

Below are listed some good practices presented in some European Quality Conferences which refer to Greece:

\section{Greece, Athens Metro}

Through application of the European Business Excellence Model (European Foundation and Quality Management / EFQM) and CAF, Athens Metro standardized operational processes and measured user satisfaction.

\section{Greece, cardiac-resuscitation Unit, Hospital "Evangelismos"}

Application of CAF revealed various organizational shortcomings of the hospital and subsequently implemented various improvement practices, such as electronic archiving files, digitization of call center, improvement materials and technical infrastructures etc. 


\section{Greece, Municipal Organization for Health and Social Affairs (DOKPY), Municipality of Nea Ionia, Volos}

This non-profit organization, within social welfare, created support structures in the municipality, thus promoting primary health care in the city supporting mainly socially vulnerable groups.

\section{Greece, Validation of Applications and Issue of Marketing Authorizations Division (DDYEP)}

This directorate is the first point of contact of pharmaceutical companies, seeking marketing approval of products in the Greek market. It is one of the nine directorates of the National Organization for Medicines (EOF), with the last one being in charge of protecting public health in relation to the marketing of medicinal in the Greek market.

DDYEP collects applications for the authorization of medicinal products and collaborates with other directorates of EOF, which carry out the evaluation and monitoring of these products. The next step for directorates is to decide on the renewal or revocation of the marketing authorizations for the medicinal products.

DDYEP has certification of international quality standard ISO 9001: 2000 since 2006 and in 2007 applied for first time CAF. A good practice of CAF is the function of a web application appointment (e-appointment) system for filing claims, which actually assessed and yielded to DDYEP the first National Quality Award (21/12/2007).

Such web application has enabled better management of appointments and coordination of the actions of workers, thus optimizing the results of the directorate and increasing the quality of customer satisfaction. Moreover, as a consequence of the principles of Quality Management, an increase in transparency was recorded together with simplified administrative procedures. Lastly, it promoted comparative modeling (benchmarking) within similar organizations in Europe.

\section{Greece, Byzantine and Christian Museum}

In 2007, this museum successfully applied CAF throughout the organization and won the second National Quality Award (21/12/2007). The applica- tion of CAF enabled determining weaknesses of the organization and facilitated the overall efficiency of its actions. A good practice that was applied was the creation of a tactile path of the museum's permanent exhibition for the blind and visually impaired.

This path includes a tour using acoustic driver and specific descriptive "tags" in the language of Braille. Also, the Byzantine and Christian Museum develops partnerships with international institutions and museums in other countries, with the aim of comparative modeling of the issues that have to do with the access to cultural sites and the increase in the number of visits to the museum.

\section{QUALITY AS AN INTEGRAL PART OF PUBLIC MANAGEMENT}

TQM was first used in the private sector in order to achieve single monitoring and evaluation of all activities of an organization in order to accomplish exceptional business results (Matei and Andreescu, 2005). "Quality" is a general concept, but not new to the public sector. In contrast, quality was, at least implicitly, a sense of public administration from the creation of modern administration, when it was connected with the observance of regulations and procedures, the formal correctness, sustainability and the absence of arbitrary decisions (Engel, 2003).

According to Giannakopoulou (2011), an emphasis was placed on the importance of quality in the public sector with the introduction of Management by Objectives (MBO) at the end of the 1960s. This was a transitional period, where for the first time an attempt was made to connect the scope of public service with the generated results.

A survey on the occurrence of quality in public administration can be found in Engel (2003), which emphasizes the idea according to which the "push for quality" was presented in the public sector during the last half of 1980s (Massey, 1999). This idea has moved the concept of quality from the private to the public sector, and on a wider scale in the 1990s, allowing the quality to become "a central term in contemporary rhetoric" (Pollitt and Bouckaert, 1995), one of the key issues and concerns of administrative modernization in Western Europe and the "OECD world" or even "a recent epidemic" of putting the citizen as the key factor in achieving quality (Pollitt and Bouckaert, 2000). 
Initially, the movement of quality was based on European Citizens Maps (Citizens' Map in United Kingdom, 1991; Charter of Public Service in France, 1992; Users' Map in Belgium, 1993) to increase the quality of services, as perceived by the users of services (Staes and Thijs, 2005). It is the commitment of an organization to the citizen regarding the quality of services provided, such as political commitment implementing the projects, identification of specific budget objectives of the Public Service (Passas, 2010).

In the late 1990s, a number of different models of quality in the public sector was applied (EFQM, ISO, CAF) and several EU Member States took initiatives to promote quality in public services. It was apparent then that the tools of TQM can contribute to a growth mechanism in the public sector, through combining compliance standards with the needs, requirements and expectations of the citizen - client to achieve efficiency, upgrading functions of services, reliability and consistency in performance, reducing failures, improving the productivity of services and changing attitudes of the workers while increasing their efficiency.

Consequently, TQM is considered as a "holistic» tool, which started to be increasingly more applied in the public sector as of late 80s (Matei and Andreescu, 2005; Matei and Lazar, 2011).

\section{BASIC DIFFERENCES BETWEEN TRADITIONAL MANAGEMENT AND TQM}

Compared to other approaches that place an emphasis on dominant characteristcs of efficiency, TQM is synthetic and covers all key indicators of competitiveness, as well as a wide range of methods and techniques to improve products, services and processes.

Quality in the public sector has evolved in three main phases:

- The quality in the sense of respect for rules and procedures.

- The quality in the sense of efficiency.

- The quality of the concept of citizen satisfaction - customers.

Table 1 illustrates the basic differences between traditional management and TQM.

During the implementation stage of TQM, a truism that employees will produce high-quality products and services, goes without saying, only when the quality concept has been mastered by all member of the private or public organization (Oakland and Porter, 2003).

TQM could help to address public issues and change public administration culture. It is a set of new practices and methods, applied by public or

\begin{tabular}{ll}
\hline \multicolumn{1}{c}{ Traditional management } & TQM \\
\hline Priority on cost & Quality wins \\
\hline Quality costs & Continuous quality improvement \\
\hline Satisfaction specifications & Proactive treatment \\
\hline Reactive treatment & Quality \& quantity \\
\hline Quality or quantity & Cost \& quality \\
\hline Cost or quality & Senior managers co-responsible for quality \\
\hline Senior managers responsible for quality & Focus on preventing defective \\
\hline Emphasis on quality control & Resetting defective \\
\hline Acceptable level of defective & Market orientation \\
\hline Product orientation & How the problem is solved \\
\hline Who is responsible & Focus on product design, process \& production \\
\hline Focus on production & Systematic cost measurement \\
\hline Suspicions about the cost of quality & Poor quality sources: managers \& workers \\
\hline Poor quality sources: workers & Discover \& explore the quality problem \\
\hline Correction or hide defective & Responsibility for quality: all functions of the organization \\
\hline Responsibility for quality: the quality control department & Quality is a management \& technical problem \\
\hline Quality is a technical problem & and \\
\hline Table 1 - Basic differences between Traditional
\end{tabular}

Table 1 - Basic differences between Traditional Management and TQM.

Source: Dervitsiotis (2005, p. 57). 
private organizations, and aims at consumer's-citizen's satisfaction and strengthening of human resources, which unlike traditional management focus on different points.

Based on the principles of TQM, some quality models have been applied in both the private (European Foundation of Quality Management - EFQM) and public (Common Assessment Framework $\mathrm{CAF}$ ) sectors with the aim to improve the overall efficiency.

\section{REASONS FOR ADOPTION OF TQM}

The management of a public or a private organization can be driven by the adoption of TQM in order to increase the competitiveness and efficiency through quality achievement. The main reasons for TQM adoption are:

- the need for survival and development of the organization in a highly competitive environment;

- inability of other approaches and tools for quality assurance;

- inefficiency of mechanistic processes, combined with the absence of adequate administrative infrastructure to improve the organization;

- the revenue growth by reducing quality failures;

- the innovation in the method of product or service creation (Dervitsiotis, 2005).

The prerequisite for the successful application of TQM is teamwork and commitment of each member in the chain to connecting everyone involved with the organization and cohesion in this embodiment. Moreover, the teamwork ensures creativity, participation and development of the worker. In order for this to happen, it is necessary to provide proper guidance and commitment on the part of the administration, as well as the proper climate on the part of employees. It is important not to feel compelled to follow mechanistic processes, but to feel that they contribute significantly to the achievement of quality and customer - citizen satisfaction.

\section{OBSTACLES TO THE IMPLEMENTATION OF TQM}

Successful implementation of TQM could lead to some direct and indirect benefits, including enhanced competitive position, higher productivity, reduced costs and better cost management, the in- creasing faith (in terms of customers) and maintaining or even better, improving employee morale (Chen et al., 2004).

However, some obstacles may appear in the implementation of TQM, as follows: (Zavlanos, 2006):

1. Fallacy of the concept, principles and elements of TQM. TQM requires continuous and permanent change.

2. Lack of involvement of the administration. Without the support of senior management, efforts will be futile (Chen et al., 2004).

3. Difficulty of culture change, which prevails in the organization.

4. Lack of attitude in the public administration focused on the citizen / customer, as well as the lack of competitive environment.

5. Orientation of the public sector in the service of a "political clientele".

6. Rigid wage system and lack of motivation.

7. Blockade people - keys from active participation in the proceedings.

8. Degraded "psychological" environment (recognition - reward).

9. Civil human resource management (general rather than specialized education and training, lack of job descriptions, rigid hierarchy, political interference, lack of mobility and flexibility of staff, static and undifferentiated payroll, etc.).

10. Lack of measurability and performance assessment.

11. Inadequate use of data. The information should be reliable, the measurement process must be consistent and data recovery methods should be satisfactory (Chen et al., 2004).

12. Lack of cooperation and teamwork between different working groups.

13. Focus on short-term profits rather than longterm goals.

14. Insufficient resources and lack of continuous resource commitment

15. Launching accusations and reprimands creating lack of mutual trust and respect among employees.

16. Lack of foresight common mission or guiding principles.

17. Lack of strategic direction and review priorities.

18. Existence of bureaucracy in the organization.

19. Administrative failure to recognize or reward goal achievement of the objective (Chen et al., 2004; Stashevsky and Elizur, 2000). 
INNOVATION AND PUBLIC ORGANIZATIONS

Innovation in the public sector is a concept which is characterized by more uncertainty than innovation in the private sector (Hartley, 2005). Usually, it refers to both changes in the relationship of the organization with the public as well as among members of the organization. The application of TQM techniques in public services is an innovation (Zampetakis and Moustakis, 2007).

On the one hand, it takes more time to occur because of the hierarchical structure of the majority of public institutions. On the other hand, it happens because of liability assurance systems (Halvorsen et al., 2005). It is not intended to create financial gain and may take on various form (Zampetakis and Moustakis, 2007; Bessant, 2003; Llewellyn and Jones, 2003) such as new products (e.g. new instruments in the hospital), new services to citizens (e.g. medical home help, electronic filing of tax returns), new procedures (e.g. administrative reorganization for a shorter period of time).
Along with the above-stated, innovations may be conceptual or rhetorical, as is the concept of TQM, and strategic innovations (including new objectives and targets).

\section{E- GOVERNMENT}

The OECD considers e-Government a powerful tool to transform the structures, processes and culture of government and make them more efficient, user-oriented and transparent. OECD defines e-Government as "The use of Information and Communications Technologies (ICT), in particular the Internet, to achieve better government" (OECD, 2003a).

The e-Government aims at: improving the government efficiency, improving the quality of services, improving the relationship between the government and its citizens.

ICT plays a very important role in NPM and it offers new possibilities and improves the existing ones. Through the implementation of e-Government, countries will achieve increased transparen-

\begin{tabular}{|c|c|}
\hline Direct benefits & Indirect benefits \\
\hline Saving transaction costs & Being user friendly and easy to use \\
\hline High speed accessibility & Easy to find information \\
\hline $\begin{array}{l}\text { Reducing customers' time spent on travelling } \\
\text { to government offices }\end{array}$ & $\begin{array}{l}\text { Convenience and availability (i.e. } 24 \text { hours a day, } \\
7 \text { days a week) }\end{array}$ \\
\hline Decreased customer queuing time & $\begin{array}{l}\text { Keeping customers' personal and financial information } \\
\text { protected }\end{array}$ \\
\hline Decreased face-to-face interaction & Keeping customer's data private (privacy) \\
\hline Saving petrol costs & $\begin{array}{l}\text { Giving customers caring and individual attention } \\
\text { (i.e. referral to a contact person) }\end{array}$ \\
\hline Saving parking costs & Providing up-to-date information \\
\hline Providing faster access to documents and forms & $\begin{array}{l}\text { Encouraging active participation from citizens } \\
\text { (i.e. consultation) }\end{array}$ \\
\hline Having a quicker response time to queries & Communicating in a clear and plain language \\
\hline Saving postages costs & $\begin{array}{l}\text { Providing prompt service and helpful response to } \\
\text { customer requests }\end{array}$ \\
\hline \multirow[t]{5}{*}{$\begin{array}{l}\text { Reducing the number of customer visits } \\
\text { to government offices }\end{array}$} & Providing dependable and reliable services \\
\hline & Making interaction with government less bureaucratic \\
\hline & Increasing customer loyalty and encouraging repeat visits \\
\hline & Being accessible to people with disabilities \\
\hline & Increasing government accountability to citizens \\
\hline
\end{tabular}

Table 2 - Citizen benefits from E-Government.

Source: Wong et al. (2011, p. 18-19). 
cy and strengthen democracy by increasing citizen participation in public administration, improving the quality of life, increasing productivity, efficiency and effectiveness of the public sector.

Some researchers believe that e-Government is the only way towards achieving that goal. It is already in our daily lives, which changes radically, hopefully in a better way. The traditional form of public service changes and a more innovative and more effective public administration profile is adopted. Besides planning, legal and institutional frameworks, policy decisions or advertising campaigns, it is of crucial importance for people to adopt, advocate and take an active part in such changes.

The benefits from e-Government are achieved through different stages and at different levels for each country. Initially, these are achieved with the full provision of information to citizens and businesses. Subsequently, this should be linked with the previous sentence, thus enabling active interaction between the citizen and the government. At the next stage, the ability to make electronic transactions becomes feasible and finally, the implementation of e-democracy.

Table 2 illustrates the direct and indirect benefits stemming from e-Government.

\section{CHANGE MANAGEMENT}

Change in knowledge is easy and requires less time to be achieved rather than changes in the attitude of an individual, individual's conduct or even changes in a group behavior. It is of the utmost importance to perceive teamwork as a very important part of TQM model that induces the change (Oakland and Porter, 2003).

Change in the group behavior is treated by managers with skepticism and is not easily accepted, as it is commonly perceived by people as a transition from a known state to another unknown and nonthreatening desired state (Bradley, 2000).

In fact, people do not react in the same way to the process of change. Figure 2 depicts a sample of individuals with different perceptions on a proposed change. The distribution of Figure 2 is normal, which means that around the average has the same probability in symmetrical values. The diagram and the rates are indicative.

The vast majority of people is positioned in the middle part of the distribution ("bell") and is more conservative. Those who move (from the center) just to the left side of the "bell" hide their response through their apathy. Those who move (from the center) just to the right of the "bell" try to earn

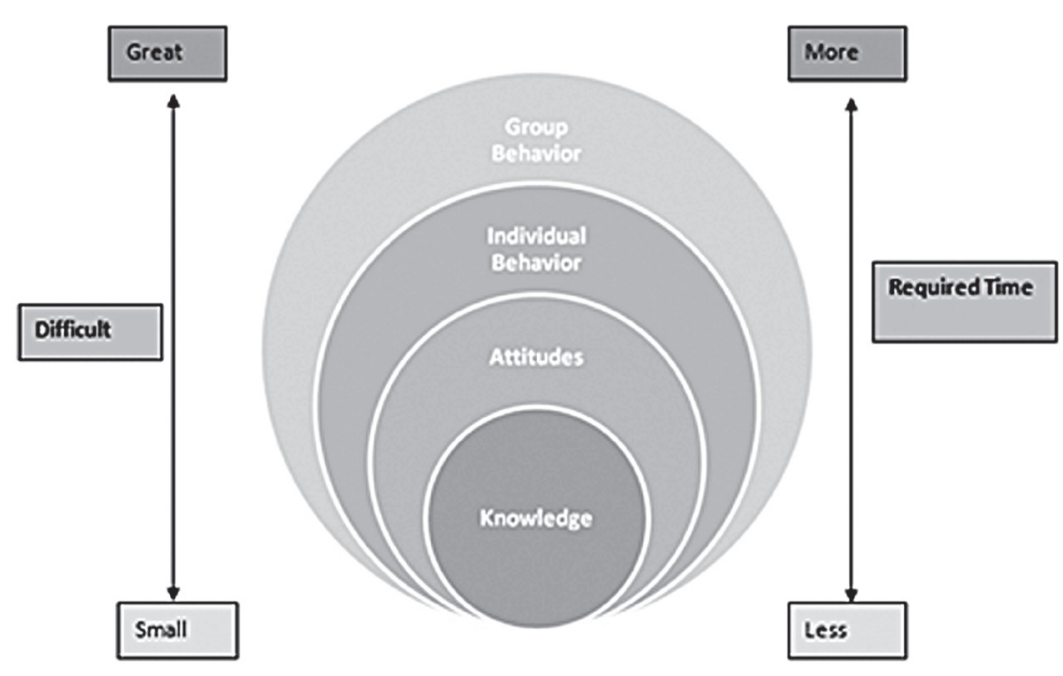

Figure 1 - Proportion of time and difficulty of achieving change (four levels).

Source: Hersey et al. (2011). 


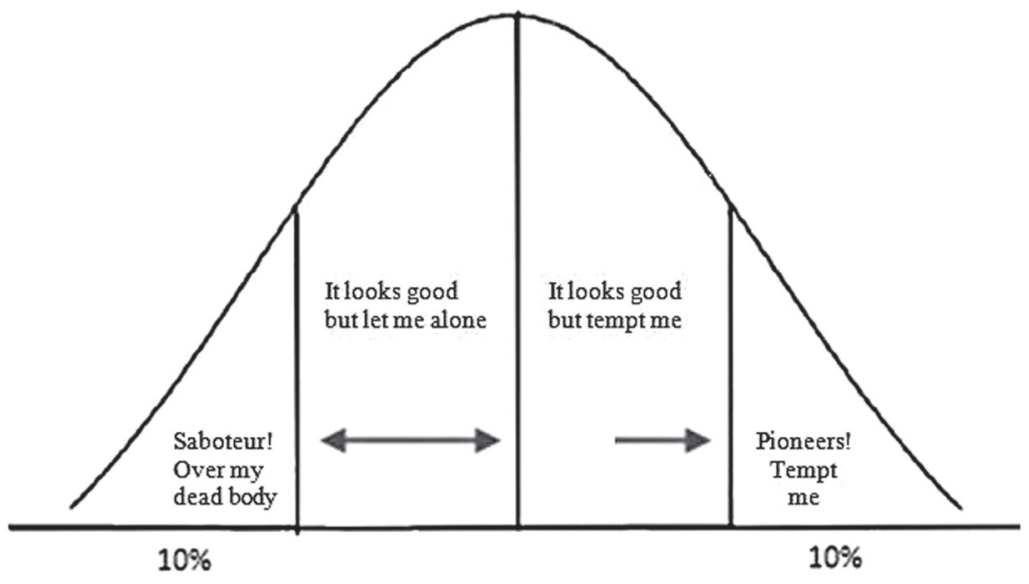

Figure 2 - Distribution of individuals with respect to propensity for change.

Source: Moustakis (2012, p. 157).

something before they join the change process. The "pioneers" guide change while "saboteurs" react to it and undermine it.

The dual direction of the arrow in Figure 2 in the cautious area (in the middle of the "bell" and left) illustrates the tendency of people in this group to move left or right (Moustakis, 2012).

The type of change is

$$
\mathrm{C}=[\mathrm{A} \times \mathrm{B} \times \mathrm{D}]>\mathrm{X}
$$

where:

$\mathrm{C}=$ Change,

A = Level of dissatisfaction with the status quo,

$\mathrm{B}=$ Desirability of the proposed change or end state,

$\mathrm{D}=$ Practicality of the change (minimal risk and disruption),

$\mathrm{X}=$ "Cost of changing".

The factors A, B and D must override the factor $\mathrm{X}$ in order for a change to happen (Cameron and Green, 2004).

Whether a change is successful (Moustakis, 2012), is a patchwork of the following factors:

$$
\mathrm{K} \times \mathrm{C} \times \mathrm{W}
$$

where:

$\mathrm{K}=$ Know. Team members should be well-aware of what they should do.
$\mathrm{C}=$ Can. Team members should have the opportunity to do what they should do, namely, they can do it.

$\mathrm{W}=$ Want. Team members want to do what they should do.

If one of the three factors of equations (1) or (2) is zero, or near zero, the overall product will also be equal to zero, or near zero.

Human resources are the most important factor in change management process (Smye and Cooke, 1994). No matter how perfect it may be, no system could be applied successfully and effectively, if human resources are unwilling to accept and use it (Bowen, 1986).

\section{RESISTANCE TO CHANGE}

Resistance represents a social and psychological phenomenon. We are all creatures of habit and any change brings people forward into the unknown (James, 1998). People who work in the same way for years may have forgotten how to learn.

The process of change is a time consuming process, during which different forces collide (resistance forces and thrusts). The duration of the process depends on the situation in which the organization wants to move up in relation to the current situation in which it is located. The greater the gap between them, the longer the process will be. 


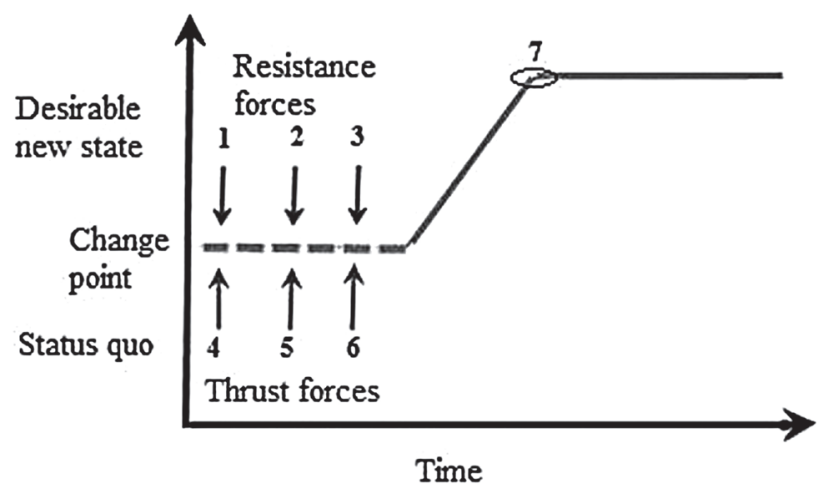

Figure 3 - Relation between (required) time and introduction of change.

Source: (Adapted from) Robbins (1998, p. 640) \& Burtonshaw-Gunn (2008, p. 18).

Therefore, the process of change is a dynamic process that must be constantly adjusted to the current requirements and needs, where in order to be completed (7), the resistance forces $(1,2,3)$ should be reduced and the thrust $(4,5,6)$ forces should prevail (Figure 3).

The reasons that force people to resist to the change may be the following:

I. Fear. The unknown creates fear. If the unknown is neutralized, one important factor will be eliminated. The reduction of fear can be achieved by (a) proper communication and (b) announcement of results which will have the program of change, the implementation process and the positive aspects of the change, such as new experiences and skills (James, 1998).

II. Personal interest. Some believe that the change will result in these negative effects (James, 1998; Kotter et al., 1986). Thus, we shall attempt to prevent change by creating rival "camps" or conflicting groups within the organization itself. To this end, it is necessary to provide reassurance and clarification as regards its future position in the organization.

III. Lack of confidence combined with a misunderstanding that either existed prior experience or created due to lack of efficient communication (Kotter et al., 1986).

IV. Habit. Some people are accustomed to working in a particular way. The nature of the change program will determine how much the work habits of each will be affected. In some cases it requires assurance, training, education and other support (James, 1998).

V. Different opinions or estimates of the benefits of change. As people act according to their own perceptions (and not with any reasonable set of events), there will be different views on the proposed change (Rosenfeld and Wilson, 1999). Many executives assume that employees understand the problem and the proposed solutions in the same way considering that everyone has the same level of access to information. However, this is never the case. In order to address the problem and ensure commitment to change, it is necessary to increase communication and effort.

VI. Low tolerance for change. This means that not all people have the same volatility to change. Some are open to change while others are very hesitant. Drucker (2012) states that there are limits to the ability of individuals to manage change. Even those who have a high resistance to change can reach their limits. Some executives mention the "change fatigue" as it seems to have no end and refer to it as if it were some kind of organizational illness (Rosenfeld and Wilson, 1999). For this reason, the goals of change must be realistic and provide flexibility.

Table 3 interprets different stages of Figure 3 showing the indications and the needs of each stage/ phase. 


\begin{tabular}{clll}
\hline Stage & \multicolumn{1}{c}{ Phase } & \multicolumn{1}{c}{ Indications } & \multicolumn{1}{c}{ Needs } \\
\hline 1 & Immobilization/Numbness & Inactivity/shock & Adjustment time \\
\hline 2 & Denial/Minimization & Acts as if nothing changed & Patience \\
\hline 3 & Frustration/Self doubt or depression & Awareness of the need to change & Tolerance \\
\hline 4 & Acceptance & $\begin{array}{l}\text { Obvious need to move to the new } \\
\text { situation }\end{array}$ & Acceptance \\
\hline 5 & Development/Testing & $\begin{array}{l}\text { Acquisition of new skills \& } \\
\text { knowledge }\end{array}$ & Growth \& succeed \\
\hline 7 & Application/Searching for meaning & $\begin{array}{l}\text { New knowledge and views are } \\
\text { applied. Reflection period }\end{array}$ & $\begin{array}{l}\text { Encouragement to take } \\
\text { initiatives \& responsibilities }\end{array}$ \\
\hline 7 & Completion/Internalization & $\begin{array}{l}\text { Adequacy \& ability } \\
\text { Give self permissions }\end{array}$ \\
\hline
\end{tabular}

Table 3 - The process of change.

Source: (Adapted from) Burtonshaw-Gunn (2008, p. 18-19)

Some researchers believe that most people react to imposition of the change or to the manner in which change is imposed to them and not to the change itself (Fuegen and Brehm, 2004; Knowles and Linn, 2004).

Furthermore, researchers with more sociological content opinions claim that people who wish to change need to perceive how others react to change (Ford et al., 2002; Ford et al., 2008) and can easily lose potential interesting views on a proposed change (Choi and Ruona, 2011).

Burtonshaw-Gunn (2008) developed the model of the change curve (adapted Figure 3), taking into consideration the reaction to the idea of change in order to understand the organizational change and its impact on individuals.

As shown in Figure 3, it is very important to mature the idea of change in order for it to happen successfully. The time for change depends on one's abilities, competencies, confidence and self-esteem. Managers are able to identify the stage of change for individuals and how to react to each in order to manage the process of change.

\section{CONCLUSIONS}

Some of the major issues impeding the quality of public administration include strong bureaucracy, customer approach, corruption, government arbitrariness and delay in the proceedings. Moreover, the fuzzy and indistinct legal framework, with the excessive laws, may lead a government agency to erroneous attitudes.

The modern public administration is invited to acquire outward orientation and shape conditions effective to address the social needs in order to serve the customer/citizen, emphasizing the forces of technology and TQM.

However, some recent researchers have dealt with the reactions that highlight individual's attitudes to organizational change (Wanberg and $\mathrm{Ba}$ nas, 2000). Indeed, there is evidence that resistance to change is the cause for ineffective reform efforts of organizations.

In recent years, the quality is established as a key criterion for consumer and business behavior. Consumers are increasingly aware of the quality and consider it the most important criterion when making choices. Organizations realize that change in consumer behavior and rush to adapt. The quality is now recognized as the most dynamic factor and the key for creation of competitive products and services.

The development of TQM, this new culture of management, which focuses on the human factor, can successfully meet the requirements of quality, as demonstrated by its application in organizations in developed countries. In today's competitive environment, the change culture of an organization is directed towards achieving quality and continuous improvement, as the basis for the survival of all organizations (Tsiotras, 2000). 
Most senior managers and employees perceive these changes in culture of an organization with skepticism. Such changes in the culture of an organization are not easily accepted and are commonly perceived as a transition from a known state to another, unknown, and non-threatening desired state (Bradley, 2000).

The public administration changes rapidly both nationally and internationally, which is why it is extremely important to improve the effectiveness and efficiency of public services. The need for public organizations to take a strategic role in the business environment and ongoing changes, that occur, leads them to the principles of TQM and the use of tools such as self-assessment and CAF.

The benefit of introducing TQM methods in the public sector is reflected in the awareness of the importance of quality as the totality of characteristics of goods and services which fully meet the specifications, requirements and expectations of the citizen / customer. The degradation of the principles and values of TQM will lead to deterioration of the Public Administration. In this context, public agencies should pay special attention to continuous quality improvement, customer/citizen satisfaction and the overall efficiency of an organization.

The results of the qualitative and quantitative research of Sotirakou and Zeppou (2006) in Greek public organizations revealed that the lack of specific skills, adaptability and behavior prevent organizations from making effective use of measurement's performance, which is a prerequisite for change management.

Other relevant studies conclude that both the technocratic factor of adaptability and political factors influence the acceptance and effective implementation of the performance's measurement system (Julnes and Holzer, 2001; de Waal, 2003, 2004).

Bowen (1986) and Young (2012) have also added that no matter how perfect it is, no system can be implemented successfully and efficiently, if workers are unwilling to accept and use it. Julnes and Holzer (2001) believe that it is necessary to conduct systematic investigation of the factors affecting application and acceptance of performance measurement models of public organizations.

Existing models for change management propose guidelines for the reform of institutions and processes, approaching the issue from the macroscopic point of view, without paying attention to people involved in the change process (Dover,
2003). However, Smye and Cooke (1994) emphasize that the starting and ultimate condition for survival of organizations are humans, thus emphasizing the importance and specificity of human capital.

Some recent studies have dealt with the reactions of people to attempted organizational change (Wanberg and Banas, 2000). Indeed, there is evidence indicating that resistance to change is the cause of ineffective reform efforts of organizations.

It is very important to emphasize that quality improvement is achieved through mutual effort of all the workers. Therefore, it is crucial to cultivate a mindset of quality (culture quality) throughout the length and width of each organization so that workers would be mature and ready to accept the change management model. This culture should be accompanied by excellent communication, respect and appreciation between colleagues as well as between colleagues and citizens. The adoption of quality culture requires continuous commitment of senior management to quality in order to enable the values and principles of TQM to become part of the culture of the organization.

Even though the TQM journey may hide some obstacles and difficulties, both individuals and organizations need to be driven by this philosophy in order for the change management to mature and develop attitudes and cultures that will lead to the optimization of the efficiency and effectiveness of individuals, organizations and the society as a whole.

\section{REFERENCES}

Bessant, J.R. (2003). High-involvement innovation: Building and sustaining competitive advantage through continuous change. Hoboken, NJ: Wiley.

Bovaird, T., \& Löffler E. (2002). Moving from excellence models of local service Delivery to benchmarking of good local governance. International Review of Administrative Sciences, 68(1), 9-24. DOI:10.1177/0020852302681001.

Bovaird, T., Löffler, E., \& Parrado-Díez, S. (2002). Developing local governance networks in Europe. BadenBaden: Nomos.

Bowen, D.E. (1986). Managing customers as human resources in service organizations. Human Resource Management, 25, 371-383. DOI: 10.1002/hrm.3930250304.

Bradley, C. (2000). Managing change. Training and Development in Australia, 27(1), 10-14. 
Burtonshaw-Gunn, S.A. (2008). The essential management toolbox: Tools, models and notes for managers and consultants. Chichester, England: Wiley \& Sons.

Cameron, E., \& Green, M. (2004). Making sense of change management: A complete guide to the models, tools \& techniques of organizational change. London: Kogan Page.

Chen, H.-K., Chen, H.-Y., Wu, H.-H., \& Lin, W.-T. (2004). Implementation in a healthcare and pharmaceutical logistics organization: The case of Zuellig Pharma in Taiwan. Journal of Total Quality Management and Business Excellence, 15(9-10), 1171-1178. DOI: $10.1080 / 1478336042000255550$.

Choi, M., \& Ruona, W.E.A. (2011). Individual readiness for organizational change and its implications for human resource and organization development. Human Resource Development Review, 10(1), 46-73. DOI: $10.1177 / 1534484310384957$.

Daemen, H., \& Schaap, L. (2000). Citizen and city: Developments in fifteen local democracies in Europe. Delft: Eburon.

Denhardt, R.B., \& Denhardt, J.V. (2000). The new public service: Serving rather than steering. Public Administration Review, 60(6), 549-559. DOI: 10.1111/00333352.00117 .

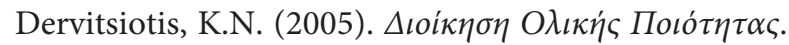
Athens: Law Library. (in Greek).

de Waal, A.A. (2003). Behavioral factors important for the successful implementation and use of performance management systems. Management Decision, 41(8), 688-697. DOI: 10.1108/00251740310496206.

de Waal, A.A. (2004). Stimulating performance - driven behavior to obtain better results. International Journal of Productivity and Performance Management, 53(4), 301-316. DOI: 10.1108/17410400410533890.

Dover, P. (2003). Change agents at work: Lessons from Siemens Nixdorf. Journal of Change Management, 3(3), 243-257. DOI: 10.1080/714042535.

Drucker, P. (2012). Managing in a Time of Great Change. Hoboken: Taylor and Francis.

Engel, C. (2003). Quality management tools in CEE candidate countries: Current practice, needs and expectations. Maastricht: European Institute of Public Administration.

Ford, J.D., Ford L.W., \& D’Amelio, A. (2008). Resistance to change: The rest of the story. Academy of Management Review, 33(2), 362-377. DOI:10.5465/ AMR.2008.31193235

Ford, J.D., Ford, L.W., \& McNamara, R.T. (2002). Resistance and the background conversations of charge. Journal of Organizational Change Management, 15(2), 105-121. DOI: 10.1108/09534810210422991.
Fuegen, K., \& Brehm, J.W. (2004). The intensity of affect and resistance to social influence. In Knowles, E.S., \& Linn, J.A., Resistance and persuasion. Mahwah, NJ: Lawrence Erlbaum Associates.

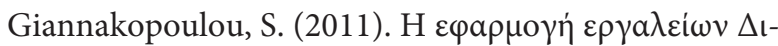

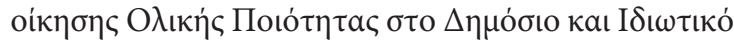

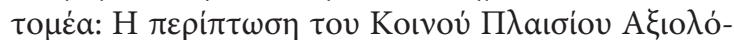

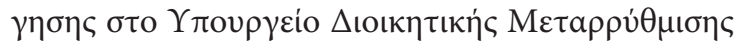

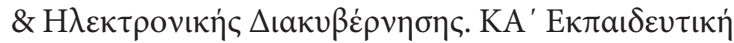

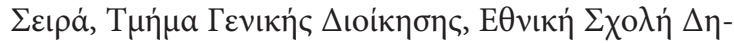

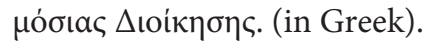

Halvorsen, T., Hauknes, J., Miles, I., \& Røste, R. (2005). On the differences between public and private sector innovation. Oslo: NIFU STEP.

Hartley, J. (2005). Innovation in governance and public services: Past and present. Public Money and Management, 25(1), 27-34. DOI: 10.1111/j.1467-9302.2005.00447.x.

Hersey, P., Blanchard, K.H., \& Johnson, D.E. (2011). Management of organizational behaviour: Leading human resources. Harlow: Prentice Hall.

Hsuan-Kai, C., Hsuan-Yueh, C., Hsin-Hung, W., \& Wen-Tsann, L. (2004). TQM implementation in a healthcare and pharmaceutical logistics organization: The case of Zuellig Pharma in Taiwan. Total Quality Management and Business Excellence, 15(9-10), 1171-1178. DOI: 10.1080/1478336042000255550.

International Organization for Standardization. (2000). Quality management systems: Fundamentals and vocabulary. Geneva: ISO.

International Organization for Standardization. (2009). Managing for the sustained success of an organization: A quality management approach. Geneva: ISO.

Ivan-Ungureanu, C., \& Marcu, M. (2006). The Lisbon strategy. Romanian Journal of Economic Forecasting, 3(1), 74-83.

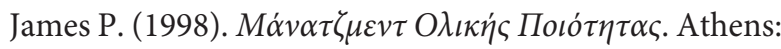
Prentice Hall. (in Greek).

Julnes, P., \& Holzer M. (2001). Promoting the utilization of performance measurement in public organizations: An empirical study of factors affecting adoption and implementation. Public Administration Review, 61(6), 693-708. DOI: 10.1111/0033-3352.00140.

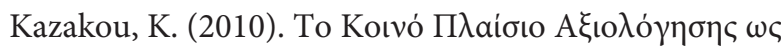

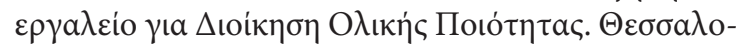

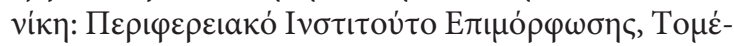
ac $\Delta \eta \mu o ́ \sigma ı v ~ M a ́ v a \tau \zeta \mu \varepsilon v \tau$. (in Greek).

Knowles, E.S., \& Linn, J.A. (2004). The importance of resistance to persuasion. In E.S. Knowles, \& J.A. Linn (Ed.), Resistance and persuasion (pp. 3-9). Mahwah, NJ: Lawrence Erlbaum.

Kotter, J.P., Schlesinger, L.A., \& Sathe, V. (1986). Organization: Text, cases, and readings on the management of organizational design and change. Homewood, IL: Irwin. 
Kuperus, H., \& Rode, A. (2008). Top public managers in Europe: Management and working conditions of the senior civil servants in European Union member States. Maastricht: European Institute of Public Administration.

Llewellyn, N., \& Jones, G. (2003). Controversies and conceptual development: Examining public entrepreneurship. Public Management Review, 5(2), 245266. DOI: $10.1080 / 1461667032000066426$.

Luijn, H., Keuzenkamp, S., \& McDonnell, S. (2004). Does leave work: Summary. Den Haag: Sociaal en Cultureel Planbureau.

Massey, A. (1999). Public Policy and Administration. Quality Issues in the Public Sector, 14(3), 1-14. DOI: 10.1177/095207679901400301.

Matei, L., \& Lazăr, C.G. (2011). Quality management and the reform of public administration in several states in South-Eastern Europe: Comparative Analysis. Theoretical and Applied Economics, 18(4), 65-98.

Matei, A., \& Sabin Andreescu, S. (2005). Managementul calității totale în sectorul public: Experiențe europene. In International Conference of Public administration at the beginning of the third millennium: Disseminating the best Japanese practices in Romania, 21-22 Novembre 2005 (pp. 50-58). Bucharest: Facultatea de Administrație Publică. (in Romanian).

Matheson, A., \& Hae-Sang, H. (2003). Public sector modernization: A new agenda. OECD Journal on Budgeting, 3(1), 7-23.

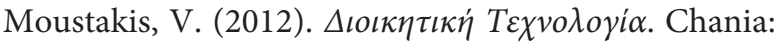
Disigma. (in Greek).

Oakland, J.S., \& Porter, L.J. (2003). TQM: Text with Cases. Burlington: Elsevier.

OECD. (2001). Education at a glance: OECD indicators 2001. Paris: Organisation for Economic Co-operation and Development. DOI: 10.1787/eag-2001-en.

OECD. (2003). The e-Government Imperative. OECD Journal on Budgeting, 3(1), 61-96.

Passas, P. (2010). Texts of application tools of public management in Greek public administration: Lecture notes. Athens: National School of Public Administration. (in Greek).

Pollitt, C., \& Bouckaert, G. (1995). Quality improvement in European public services: Concepts, cases and commentary. London: Sage.
Pollitt, C., \& Bouckaert, G. (2000). Public management reform: A comparative analysis. Oxford: Oxford University Press.

Robbins, S.P. (1998). Organizational behavior: Concepts, controversies and applications. Upper Saddle River, NJ: Prentice Hall.

Rosenfeld, R. H., \& Wilson, D. C. (1999). Managing organizations: Text, readings and cases. London: McGrawHill Publishing Company.

Smye, M., \& Cooke, R. (1994). The key to corporate survival: change begins and ends with people. In L.A. Berger, M.J. Sikora, \& D.R. Berger (Ed.), The change management handbook: A road map to corporate transformation. New York: McGraw-Hill.

Sotirakou, T., \& Zeppou, M. (2006). Utilizing performance measurement to modernize the Greek public sector. Management Decision, 44(9), 1277-1304. DOI:10.1108/00251740610707730.

Staes, P., \& Thijs, N. (2005). Quality management on the European agenda. Eipascope, 2005(1), 33-41.

Stashevsky, S., \& Elizur, D. (2000). The effect of quality management and participation in decision-making on individual performance. Journal of Quality Management, 5(1), 53-65. DOI:10.1016/S1084-8568(00)00012-2.

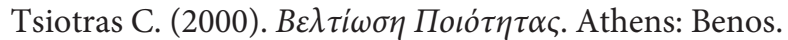
(in Greek)

Wanberg, C.R., \& Banas, J.T. (2000). Predictors and outcomes of openness to changes in a reorganizing workplace. Journal of Applied Psychology, 85(1), 132142. DOI: 10.1037/0021-9010.85.1.132.

Wong, M.S., Hideki, N., \& George, P. (2011). The use of importance-performance analysis (ipa) in evaluating Japan's E-government services. Journal of Theoretical and Applied Electronic Commerce Research, 3(2), 1730. DOI: $10.4067 /$ S0718-18762011000200003.

Young, P. C. (2012). Recursive estimation and time-series analysis: An introduction. Berlin: Springer.

Zampetakis, L.A., \& Moustakis, V. (2007). Entrepreneurial behavior in the Greek public sector. International Journal of Entrepreneurial Behaviour and Research, 13(1),19-38. DOI: 10.1108/13552550710725165.

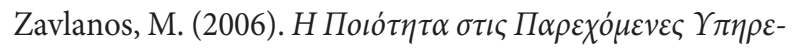

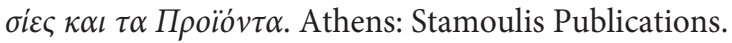
(in Greek). 


\section{REFORMA JAVNOG SEKTORA:}

\section{UPRAVLJANJE TOTALNIM KVALITETOM I UPRAVLJANJE PROMENAMA}

\section{Rezime:}

Ovaj rad bavi se pitanjem upravljanja totalnim kvalitetom (TQM) i upravljanja promenama u javnom sektoru. Poseban naglasak stavlja se na ulogu TQM-a $\mathrm{u}$ javnom sektoru, koncept kvaliteta $\mathrm{u}$ javnom sektoru usluga, inovacije $\mathrm{u}$ javnom sektoru kao i na ulogu elektronske uprave. Takođe, posebnu pažnju u radu zavređuju najzanimljivije i najinovativnije prakse koje se primenjuju u Grčkoj. Na kraju rada svi razmatrani pojmovi su integrisani sa faktorima koji oblikuju promene.

\section{Ključne reči:}

upravljanje promenama, elektronska uprava, reforma javnog sektora, javni menadžment, javne organizacije, upravljanje totalnim kvalitetom (TQM).

Received: September 16th, 2014. Correction: October 10th, 2014. Accepted: October 22nd, 2014. 